\title{
A NEW SPECIES OF PLEUROTHALLIS (ORCHIDACEAE: PLEUROTHALLIDINAE) FROM QUITO, ECUADOR
}

\author{
Martín Carrera $^{1}$, Luis Baquero ${ }^{2-5}$ \& Vlastimil ZaK ${ }^{1}$ \\ ${ }^{1}$ Universidad San Francisco de Quito USFQ, Colegio de Ciencias Biológicas y Ambientales COCIBA, \\ Herbario de Botánica Económica QUSF, Quito 170901, Ecuador \\ ${ }^{2}$ Carrera de Ingeniería Agroindustrial y Alimentos. Facultad de Ingeniería y Ciencias \\ Agropecuarias. Universidad de Las Américas, Calle José Queri, Quito 170137, Pichincha, Ecuador \\ ${ }^{3}$ Jardín Botánico de Quito, Pasaje \#34, Rumipampa E6-264 y Av Shyris, Interior Parque La Carolina, \\ Quito, Ecuador \\ ${ }^{4}$ Instituto Nacional de Biodiversidad, Pasaje Rumipamba 341 y Av. de los Shyris, 170135, Quito, \\ Pichincha, Ecuador \\ ${ }^{5}$ Corresponding author: lbaquero@hotmail.com
}

\begin{abstract}
A new species of Pleurothallis from Ecuador, Pleurothallis quitu-cara, is described, illustrated and compared with the similar species P.corysta. The new finding is a surprise for the orchid flora of Quito and its valleys.
\end{abstract}

Resumen. Una nueva especie de Pleurothallis de Ecuador, Pleurothallis quitu-cara se describe, ilustra y compara con la especie similar P. corysta. El hallazgo es una sorpresa para la flora orquidácea de Quito y sus valles.

Key words: Acronia, callus, glenion, Hoya de Quito, Pleurothallis quitu-cara

Ecuador holds about $15 \%$ of the world's described species in the family Orchidaceae, with 4,032 species of orchids, a third of which are endemic to the country (León-Yánez et al 2011, Neil 2012, Christenhusz \& Byng 2016). The diversity of orchids from Ecuador is still understudied, and new species continue to be discovered and described every year (Doucette, Portilla \& Cameron 2016, Wilson et al. 2016, Baquero 2017, Baquero \& Iturralde 2017, Baquero \& Zuchan 2017, Jost \& Iturralde 2017, Wilson et al. 2017a, b). Within the large subtribe Pleurothallidinae, several taxonomic problems have been identified at generic and infrageneric levels (Chase \& Pridgeon 2001, Karremans 2016). Traditionally, hundreds of species have been included in the genus Pleurothallis sensu lato (Luer 1986), but morphological and molecular analyses evidenced its polyphyly (Pridgeon \& Chase 2001). Several proposals to split it have been presented, with different generic and infrageneric definitions and circumscriptions (Szlachetko \& Margonska 2001, Chase et al. 2003, Luer 2005). Pleurothallis jupiter was described by Luer (1975) and placed in the section Macrophyllae-Fasciculatae Lindl. Szlachetko \& Margonska (2001) proposed the genus Zosterophyllanthos for species of section MacrophyllaeFasciculatae, but Luer (2005) resurrected the genus Acronia for previously included species in sections Acronia, Amphigya and Macrophyllae-Fasciculatae. Molecular analyses have evidenced that species of the section Macrophyllae-Fasciculatae are closely related with the type species of Pleurothallis, P. ruscifolia R.Br., thus supporting its inclusion in Pleurothallis sensu stricto (Pridgeonet al. 2001, Wilson et al. 2011, 2013). Based on morphological similarity to other member of the section Macrophyllae-Fasciculatae (Table 1), we describe here a new species as a member of the genus Pleurothallis.

\section{Results}

Plant material.- Specimens collected in 1994 are deposited in the collections of the Herbario de Botánica Económica del Ecuador QUSF. Flowers are preserved 


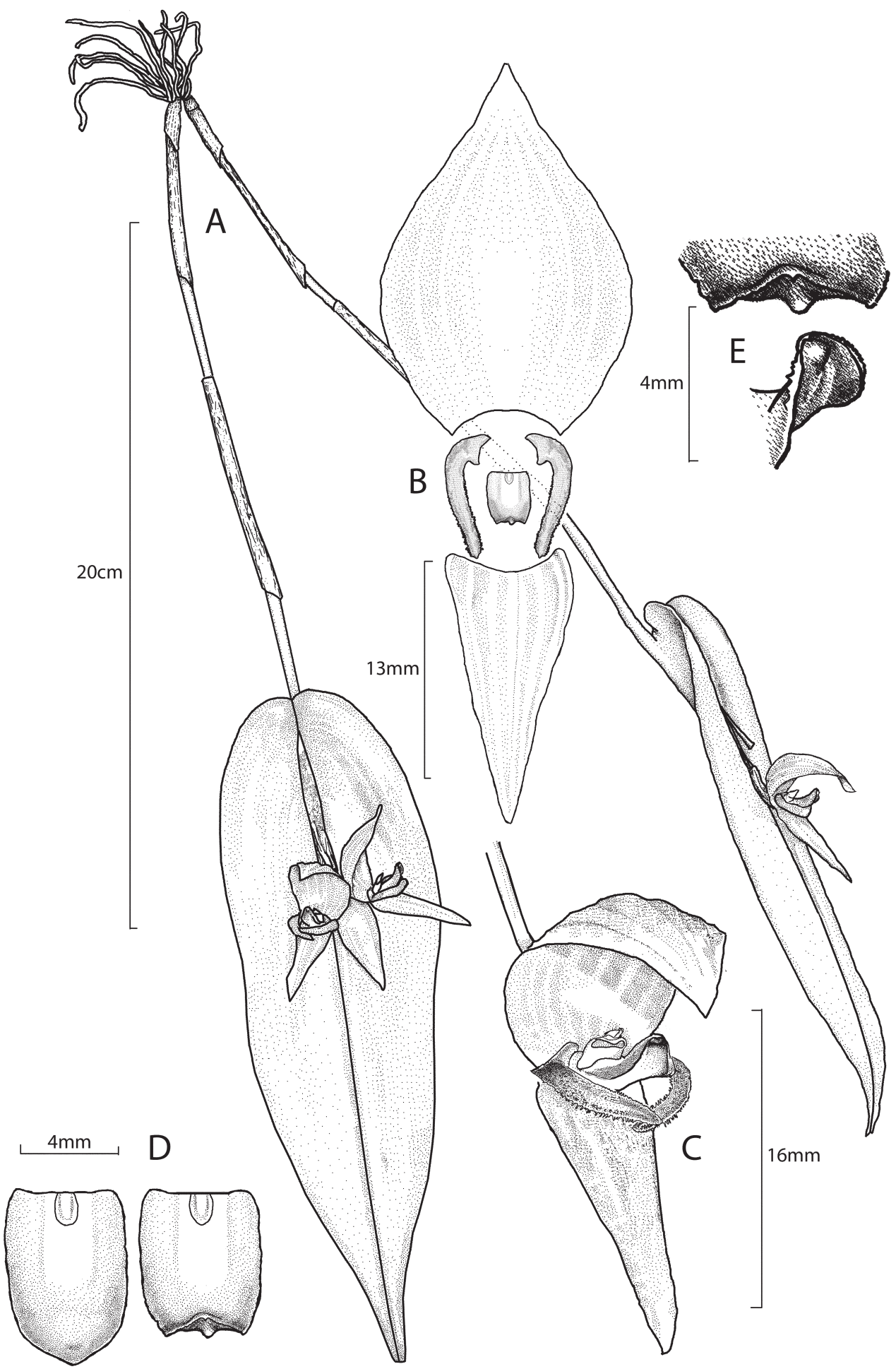

FIGURE 1. Pleurothallis quitu-cara. A, habit. B, disected flower. C, flower close-up. D, dorsal view of the lip, flattened (left), with normal bent apex (right). E, lip close up showing with portruding abaxial callus (Illustration: Luis Baquero). 
in $75 \%$ ethanol with glicerine. Living individuals were found and examined at the type locality in 2015 and 2016, but no specimens were collected, and photographs were taken in-situ. Research on the material lead to the knowledge that it belonged to a new species.

Study area.- The only known population of the new species was discovered close to Quito, in the sourthern valley of Los Chillos near Pita river.

\section{Pleurothallis quitu-cara Carrera \& Baquero, sp. nov.} (Fig. 1-3).

TYPE: Ecuador. Provincia de Pichincha: Valle de los Chillos, Río, $-0.436431^{\circ} \mathrm{S},-78.4118900^{\circ} \mathrm{W}, 2980 \mathrm{~m}$, April 10th, 1994, V. Zak 6543 (holotype: 2380 QUSF).

Diagnosis: Pleurothallis quitu-cara is similar to $P$. corysta Luer, from which it differs in the rectangular lip with an elliptical small glenion with an elevated center at the base, a minutely pubescent, protruding callus and the apex of the lip bent upwards versus the erect, subovate, without an obvious glenion and an elevated line on the disc and the apex of the lip not bent in P. corysta (Fig. 3).

Plant medium in size, epiphytic or terrestrial, caespitose, with slender roots. Ramicauls stout and glandular, pendent to horizontal, $25-35 \mathrm{~cm}$ long, with three, $8-10 \mathrm{~cm}$ long, tubular sheaths. Leaf horizontal to pendent, coriaceous, oblong, slightly undulated, leaf-margins slightly deflexed, $13-20 \times 6-8 \mathrm{~cm}$, base sub sessile, cordate to deeply cordate, apex rostrate and acute. Inflorescence a fascicle of 1-4 medium sized simultaneous flowers subtended by a spathe $1 \mathrm{~cm}$ long, peduncles 10-12 $\mathrm{mm}$ long withing the spathe; floral bracts $4.5-6.0 \mathrm{~mm}$ long; pedicel $7.0-8.5 \mathrm{~mm}$ long; ovary smooth, six-ridged, $5.0-5.5 \mathrm{~mm}$ long. Dorsal sepal deeply concave, ovate, acute, $19 \times 12$ $\mathrm{mm}, 7$ veined, sulphur-coloured (xanthic above and below) or sulphur coloured with 7 sanguine color veins (non xanthic above, below without colored veins). Lateral sepals connate into a side-decurved, lanceolate, acute synsepal, $16 \times 8 \mathrm{~mm}, 6$ veined, yellow-sulphur coloured, powdered with sanguine color glands (non-xanthic form with more obvious). Petals pubescent, deeply decurved below the lip, crescent shaped, subacute, $10.0 \times 1.8 \mathrm{~mm}$, colored as the dorsal sepal. Lip oblong, $6.8 \times 4.1 \mathrm{~mm}$, sides bent downwards, papillose, apex obtuse, apiculate, bent upwards, with a small swollen callus underneath, pubescent at the margins, the base truncate with a small elliptical glenion with an elevated center, the quadrangular disc convex, minutely pubescent, lemoncoloured above, milk-white color at the base suffused with leather-yellow in xanthic form, lemon-coloured suffused with a sanguine color above, milk-white color at the base, suffused with leather-yellow in the middle and suffused with sanguine color below in non xanthic form. Column stout, $2.5 \mathrm{~mm}$ long, $2.3 \mathrm{~mm}$ wide, foot thick, rostellum and bilobed stigma apical. Pollinia 2, yellow.

EpONYMY: Honoring Quitu-Cara, the indigenous group which originally inhabited Quito and the valley near Quito, where the known population of the new species persists.

Distribution AND habitat: Pleurothallis quitu-cara has been found only at one locality in the Hoya de Guayllabamba, valley of Los Chillos, on the canyon of the River Pita (Fig. 4). A population of approximately 50 plants of Pleurothallis quitu-cara grows at the type locality. Two color forms, a xanthic and a nonxanthic form, coexist (Fig. 2B). It is not clear if the species is always represented by this two colour forms, or other phenotypes could be found somewhere else. Nevertheless, no other populations of the species are known by the authors at the moment, which does not necessarily mean $P$. quitu-cara is restricted to this single population. More exploration is needed to confirm if this original population is the only one known for the species. This finding confirms that, even so close to Quito, the capital of a well explored country, when it comes to orchids, a new species of orchid can still be found anywhere.

CONSERVATION STATUS AND EXTINCTION RISK: The type locality of Pleurothallis quitu-cara is located in one of the most populated valleys of the northern Andes, Los Chillos. Habitat destruction in Los Chillos is extensive, mostly produced by expansion of the agricultural frontier focused on monocultures, especially for the floral industry, and expansion of the urban frontier. The few remnants of natural ecosystems in Los Chillos are found in ravines, 

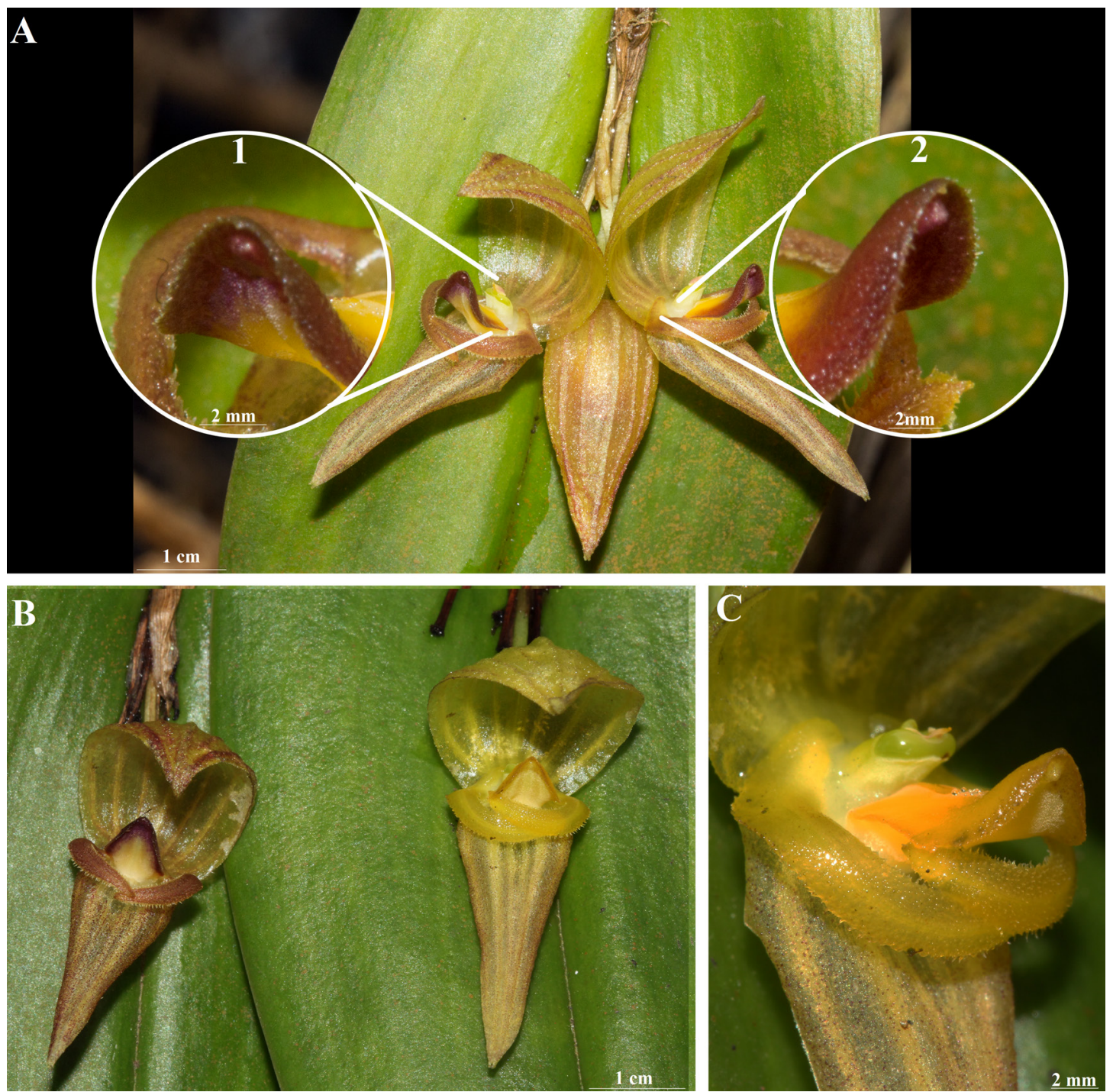

FIgure 2. Photos of Pleurothallis quitu-cara. A, leaf with a inflorescence with succesive flowers; $1=$ callus at the abaxial surface of the lip; 2 = apex of the lip bented upwards. B, two color forms, non xanthic form at the left and xanthic form at the right. C, petals notably crossed below the lip (Photos: Kilian Zuchan, Luis Baquero).

gorges and protective forests, although most of them are in precarious state of conservation. Unfortunately, the area is not under any type of formal protection. Exploration of additional surrounding canyons and surrounding areas is needed to confirm how restricted is the distribution of this new species. Urgent conservation actions are needed in order to preserve the known population of $P$. quitu-cara and other species that are restricted to the particular ecosystem. We are unaware of the presence of this new species in ex situ situations. However, it is important to remember that in situ conservation actions should lead the way to preserve biodiversity, while ex situ management by itself is only complementary and alone has little conservation impacts (Wilson et al. 2016).

Discussion. In its general shape of the flower, $P$. quitu-cara reminds some other species and speciescomplex of Pleurothallis; P. corysta, P. adonis Luer, 

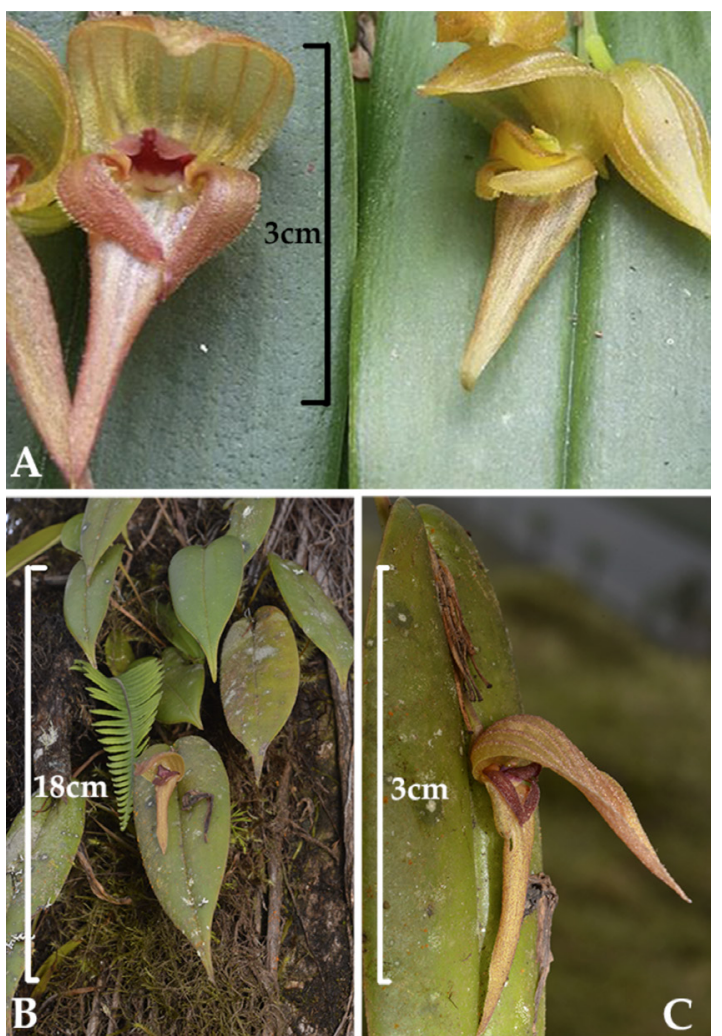

Figure 3. Comparison between Pleurothallis corysta Luer and Pleurothallis quitu-cara. A, P. corysta (left) and P. quitu-cara (right). B-C, P. corysta in situ (habit and flower). Photo by Martín Carrera (A) and Luis E. Baquero (B-C).

\section{P. linguifera Lindl., P. grandiflora Lindl., P. jupiter} Luer and P. sarcochila Garay (Table 1). It is most similar to $P$. corysta but, the size of the flowers, the pubescent, slim petals and the shape of the lip are totally different among the two species (Fig. 3). Two distinctive traits are present in P. quitu-cara lip; an elevated, microscopically pubescent, and quadrangular disc, and a small, protruding callus at the upward bent apex of the lip. Considering that the final portion of the lip bents upwards, the protrusion in the apex of the lip is most conspicuous and might have something to do with pollinator attraction. Pleurothallis corysta, on the other hand, has a similar growing habit to the new species and a swollen apex of the central vein at the apex of the lip, also similar to P. quitu-cara although the shape of the petals, the glabrous flowers and the absence

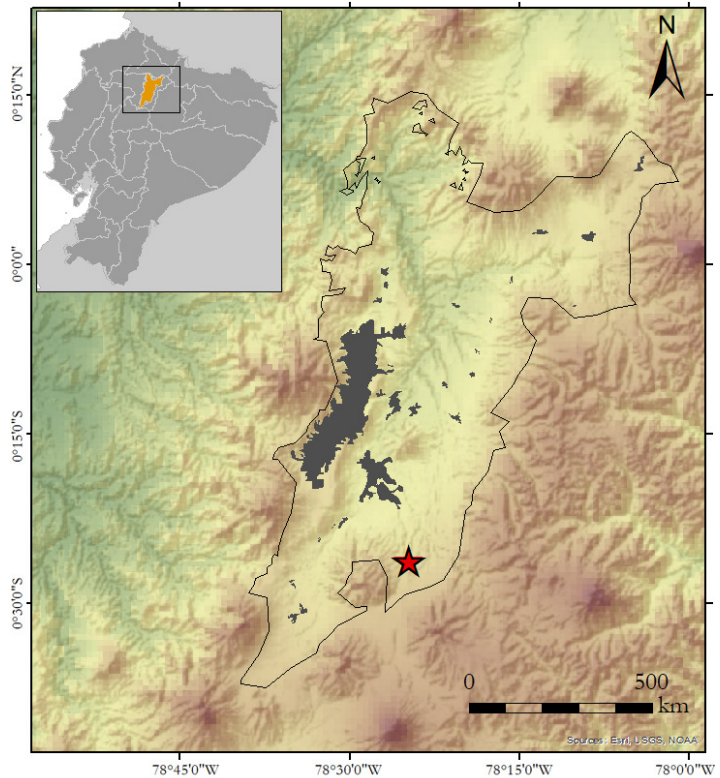

Urban Area of Quito

$\begin{array}{rr}\begin{array}{c}\text { Altitude } \\ -5879\end{array} & \text { Coordinate System: GCS WGS } 1984 \\ 1 & \text { Datum: WGS } 1984 \\ 1 & \text { Units: Degree }\end{array}$

Figure 4. Collection location of Pleurothallis quitu-cara (red star) in the gorge of "Río Pita" in "Valle de los Chillos" near Quito (Map: Emilia Peñaherrera).

of an obvious glenion separates it from P. quitu-cara (Fig. 1, 2A, 3).

ACKNOWLEDGEMENTS. We thank the anonymous reviewers for their comments. We express our gratitude to Camilo Ortiz, Emilia Peñaherrera and Kilian Zuchan for their support to our research. Laboratory work was funded by grants from Universidad San Francisco de Quito USFQ (to Vlastimil Zak). Work by Martín Carrera and Vlastimil Zak was supported by Universidad San Francisco de Quito, Colegio de Ciencias Biológicas y Ambientales COCIBAUSFQ (project ID 34). Work by Luis Baquero received funding from Universidad de Las Américas UDLA, support from Quito Botanical Garden and also support from INABIO (Intituto Nacional de Biodiversidad). Research permits were issued by the Ministerio del Ambiente de Ecuador (005-2015-FLO-DPAP-MA). 
TABLE 1. Comparison between Pleurothallis quitu-cara and other related species.

\begin{tabular}{l|l|l|l|l|l}
\hline \multicolumn{1}{c|}{ Species } & \multicolumn{1}{|c|}{$\begin{array}{c}\text { Ramicaul } \\
\text { orientation }\end{array}$} & \multicolumn{1}{|c}{ Petals position } & \multicolumn{1}{|c}{ Lip apex } & \multicolumn{1}{c}{ Glenion } \\
\hline P. quitu-cara & $\begin{array}{l}\text { Horizontal to } \\
\text { pendant }\end{array}$ & $\begin{array}{l}\text { Crossed forward in } \\
\text { front of the lip }\end{array}$ & $\begin{array}{l}\text { Bent upwards and with } \\
\text { a protruding callus in the } \\
\text { abaxial side }\end{array}$ & $\begin{array}{l}\text { Elliptical, slightly } \\
\text { elevated }\end{array}$ & $\begin{array}{l}\text { Quadrangular, } \\
\text { convex, elevated } \\
\text { and microscopically } \\
\text { pubescent }\end{array}$ \\
\hline P. corysta & $\begin{array}{l}\text { Suberect to } \\
\text { horizontal }\end{array}$ & $\begin{array}{l}\text { Downwards, } \\
\text { decurved }\end{array}$ & $\begin{array}{l}\text { Sides revolute above } \\
\text { the middle, the apex } \\
\text { narrowly obtuse with } \\
\text { the end of the mid } \\
\text { vein beneath markedly } \\
\text { swollen }\end{array}$ & Not obvious & $\begin{array}{l}\text { Subrhombic to broadly } \\
\text { elliptical. Glabrous }\end{array}$ \\
\hline P. jupiter & Suberect & $\begin{array}{l}\text { Forward (petal tips } \\
\text { touching) }\end{array}$ & $\begin{array}{l}\text { Sides bent downwards } \\
\text { and tip remains unfolded }\end{array}$ & $\begin{array}{l}\text { Broad, above the } \\
\text { base }\end{array}$ & $\begin{array}{l}\text { Subquadrate, verrucose } \\
\text { and ciliate above the } \\
\text { middle }\end{array}$ \\
\hline P. adonis & Erect & $\begin{array}{l}\text { Forward (without } \\
\text { crossing) }\end{array}$ & $\begin{array}{l}\text { Sides bent downwards, } \\
\text { tip unfolded }\end{array}$ & Small, at the base & Not given \\
\hline P. linguifera & Erect & $\begin{array}{l}\text { Forward (petals tips } \\
\text { may touch) }\end{array}$ & $\begin{array}{l}\text { Slightly bent downwards } \\
\text { with a small crest like }\end{array}$ & Small at the base & Not given \\
\hline P. grandiflora & Erect & Downwards & $\begin{array}{l}\text { Bent upwards with a } \\
\text { canal in the middle }\end{array}$ & Above the base & More or less convex \\
\hline P. sarcochila & Erect & Down and forward & Bent downwards & Not given & More or less convex \\
\hline
\end{tabular}

\section{Literature Cited}

Baquero, L. E. (2017). Scaphosepalum zieglerae, a showy new species in the genus (Pleurothallidinae: Orchidaceae). Lankesteriana, 17(2), 305-310.

Baquero, L. E. \& Iturralde, G. A. (2017). Porroglossum raoi, a new species of Pleurothallidinae (Orchidaceae) from Ecuador. Lankesteriana, 17(1), 49-54.

Baquero, L. E. \& Zuchan, K. (2017). Platystele pamelae (Orchidaceae: Pleurothallidinae), a new species from Ecuador. Lankesteriana, 17(2), 245-250.

Chase, M. W. \& Pridgeon, A. M. (2001). A phylogenetic reclassification of Pleurothallidinae (Orchidaceae). Lindleyana, 16(4), 235-271.

Chase, M. W., Cameron, K., Barrett, L. \& Freudenstein, V. (2003). DNA Data and Orchidaceae systematics: A new phylogenetic classification. In: K. W. Dixon, S. P. Kell, R. L. Barrett \& P. J. Cribb, Eds. Orchid Conservation (pp 69-68). Borneo: Kota Kinabalu Natural History Publications.

Christenhusz, M. J. \& Byng, J. W. (2016). The number of known plants species in the world and its annual increase. Phytotaxa, 261(3), 201-217.

Doucette, A., Portilla, J. \& Cameron, K. (2016). Ten new taxa in the orchid subtribe Pleurothallidinae (Epidendroideae, Epidendreae) from Ecuador. Phytotaxa, 257 (3), 230-248.

Jost, L. \& Iturralde, G. (2017). A showy new Platystele (Pleurothallidinae: Orchidaceae) from Northwest Ecuador. Lankesteriana, 17(1), 55-66.
Karremans, A. P. (2016). Genera Pleurothallidinarum: an updated phylogenetic overview of Pleurothallidinae. Lankesteriana, 16(2), 219-241.

León-Yánez, S., Valencia, R., Pitman, N., Endara, L., Ulloa Ulloa, C. \& Navarrete, H. (eds.). (2011). Libro rojo de las plantas endémicas del Ecuador, $2 a$ edición. Ecuador, Quito: Publicaciones del Herbario QCA. Pontificia Universidad Católica del Ecuador.

Luer, C. A. (1975). Icones Pleurothallidinarum. Pleurothallis of Ecuador (Orchidaceae). Selbyana, 1(1), 56-100.

Luer, C. A. (1986). Icones Pleurothallidinarum III: Systematics of Pleurothallis. Monographs in Systematic Botany from Missouri Botanical Garden, 20, 1-109.

Luer, C. A. (2005). Icones Pleurothallidinarum XXVII. Dryadella and Acronia section MacrophyllaeFasciculatae. Monographs in Systematic Botany from the Missouri Botanical Garden, 103.

Neil, D. A. (2012) ¿Cuántas especies nativas de plantas vasculares hay en Ecuador? Revistas Amazónica Ciencias y Tecnología, 1(1), 70-83.

Pridgeon, A. M. \& Chase, M. W. (2001). A phylogenetic reclassification of Pleurothallidinae (Orchidaceae). Lindleyana, 16(4), 235-271.

Pridgeon, A. M., Solano, R. \& Chase, M. W. (2001). Phylogenetic relationships in Pleurothallidinae (Orchidaceae): Combined evidence from nuclear and plastid DNA sequences. American Journal of Botany, 88(12), 2286-2308. 
Szlachetko, D. L. \& Margonska, B. H. (2001). Genera et species orchidalium. 3. Polish Botanical Journal, 46(2), 113-121.

Wilson, M., Belle, C., Dang, A., Hannan, P., Kenyon, C., Low, H., Stayton, T. \& Woolley, M. A. (2011). A phylogenetic analysis of the genus Pleurothallis, with emphasis on Pleurothallis subsection MacrophyllaeFasciculatae, using nuclear ITS and chloroplast DNA sequencing. Lankesteriana, 11(3), 369. http://dx.doi. org/10.15517/lank.v11i3.18304

Wilson, M., Belle, C., Dang, A., Hannan, P., Kellogg, L., Kenyon, C., Low, H., Mochizuki, A., Nguyen, A., Sheade, N., Shan, L., Shum, A., Stayton, T., Volz, C., Vosburgh, B., Wellman, H. \& Woolley, M. A. (2013). Preliminary phylogenetic analysis of Pleurothallis sensu lato based upon nuclear and plastid sequences. Lankesteriana, 13(1-2), 139. http://dx.doi. org/10.15517/ lank.v0i0.11568

Wilson, M., Baquero, L., Dupree, K., Jiménez, M. M.,
LeBlanc, C. M., Merino, G., Portilla, J., Salas Guerrero, M., Tobar Suárez, F., \& Werner, J. D. (2016). Three new species of Pleurothallis (Orchidaceae: Pleurothallidinae) in subsection Macrophyllae-Fasciculatae from northern South America. Lankesteriana, 16(3), 349-366. https:// dx.doi.org/10.15517/lank.v16i3.27314

Wilson, M., Baquero, L., Driessen, W., Dupree, K., Gil, K., Portilla, J. \& Salas Guerrero, M. (2017). A clarification of the distinctions between Pleurothallis talpinaria and Pleurothallis trimeroglossa (Orchidaceae: Pleurothallidinae) and an allied new species from Ecuador. Lankesteriana, 17(2), 133-151.

Wilson, M., Dupree, K., Driessen, W., Larsen, B. T., Löckher, A., Niessen, A., Portilla, J., Salas Guerrero, M., Suarez, M. A. \& Tobar-Suárez, F. (2017). A clarification of the taxonomy of Pleurothallis crocodiliceps (Pleurothallidinae, Orchidaceae) and four new species of Pleurothallis in subgenus Ancipitia. Lankesteriana, 17(2), 165-191. 
